\title{
Brown v. Curb: The Lieutenant Governor's Powers When the Governor Is Outside the State
}

In Brown v. Curb, ${ }^{1}$ the supreme court held that article V, section 10 of the California Constitution permits a Lieutenant Governor to exercise complete gubernatorial power, including the power to make judicial appointments, during the Governor's physical absence from the state. The court also held that where an appointinent requires confirmation, the Governor may withdraw the appointment up until the confirmation becomes effective.

Brown thrust the court headlong into an unusual political brawl, one betwcen a Democratic Governor and a Republican Lieutenant Governor. ${ }^{2}$ Part I of this Note sets forth the facts and the court's decision; Part II analyzes the decision and concludes that the court correctly adhered to clear legislative intent in determining the effect of a Governor's absence from the state. The decision, however, left room for similar conflicts to arise in the future, and in fact raised new questions concerning the inanner in which California's temporary disability provision is to be administered. Part III presents a proposal for legislative resolution of the problems that Brown failed to satisfactorily resolve.

\section{THE CASE}

\section{A. The Facts}

The retirement of Presiding Justice Parker Wood from the bench on December 31, 1978 created a vacancy on the California Court of Appeal. ${ }^{3}$ Governor Edmund G. Brown, Jr. selected the Honorable Bernard S. Jefferson as a candidate for the position on March 22, 1979, and sent Justice Jefferson's name to the State Bar Association Board of

1. 26 Cal. 3d 110, 603 P.2d 1357, 160 Cal. Rptr. 760 (1979) (Manuel, J.) (7-0 decision). Consolidated with Brown was a petition by the California Commission on the Governorship, entitled In re the Petition of the Commission on the Governorship of California, requesting the supreme court to decide the questions raised by the controversy in Brown. It was this petition which, under art. V, $\$ 10$ of the California Constitution, properly placed the case before the court, enabling it to consider Brown through its exercise of ancillary jurisdiction. The consolidated cases will hereinafter be referred to as Brown.

2. California does not require the Governor and Lieutenant Governor to be elected on a single ticket; see CAL. CoNST. art. V, $\$ \S 2,9$, setting forth the qualifications required for each office.

3. Second Appellate District, Division One. 
Governors for evaluation. ${ }^{4}$

On March 26, 1979, Governor Brown flew to Washington, D.C. to testify before the Senate Committee on Energy and Natural Resources. He was absent from California for approximately forty hours. On March 27, during the Governor's absence, Lieutenant Governor Mike Curb appointed Judge Armand Arabian to fill the vacancy on the court of appeal..$^{5}$ The Lieutenant Governor made this appointment despite his knowledge of Governor Brown's intention to appoint Justice Jefferson. ${ }^{6}$

Upon his return to California, Governor Brown withdrew the Arabian appointment and sent Justice Jefferson's naine to the Commission on Judicial Appointments for confirmation. Lieutenant Governor Curb objected to the withdrawal of the Arabian appointment, claiming that the commission was obligated "to go forward with a confirmation learing with respect to Judge Arabian before turning to any other appointments that might have been made subsequent to . . . the appointment which is now pending before the commission."7

The Commission on Judicial Appointments did not act on either of the two conflicting appointments; rather, it asked the Governor and the Lieutenant Governor to respond to several questions pertaining to the dispute. ${ }^{8}$ On May 7, 1979, Governor Brown and Justice Jefferson filed a petition for writs of mandate and prohibition with the suprene court, ${ }^{9}$ seeking to compel the commission to consider only the Jefferson

4. Letter from Governor Brown to Chief Justice Bird in her capacity as Chairperson of the Commission on Judicial Appointınents (March 30, 1979). The practice of submitting judicial candidates to the Board of Governors for evaluation has been followed in California since the governorship of Earl Warren. Smith, The California Method of Selecting Judges, 3 STAN..L. REv. 571, 595-96 (1951).

5. The appointment was made by a letter from Mike Curb to Chief Justice Rose Bird, Chairperson of the Commission on Judicial Appointments. To become effective, an appointment to the appellate court must be confirmed by this commission. CAL. Const. art. VI, $\$ 16(d)$.

6. The Lieutenant Governor was informed that the Governor had already sent Jefferson's name to the State Bar Board of Governors for evaluation, and that the appointment of Judge Arabian would be withdrawn by Governor Brown if the Lieutenant Governor went through with the Arabian appointment. Affidavit of Gray Davis, Executive Secretary to the Governor (May 4, 1979).

7. Letter from Lieutenant Governor Curb to the Commission on Judicial Appointments (April 2, I979).

8. Letter from Rose Bird, Chairperson of the Commission on Judicial Appointments, to Governor Brown and Lieutenant Governor Curb (April 16, 1979). The questions posed by the commission were: (1) Does the Lieutenant Governor have the power to make an appointment to the court of appeal while the Governor is temporarily out of the state? (2) If so, does the Governor have the power to withdraw such an appointment upon his return and prior to confirmation by the commission? (3) In these circumstances, should the Commission on Judicial Appointments decide which appointment or appointments it believes are properly pending before the commission?

9. Petition for Writs of Mandate and Prohibition and for Declaratory Rehef, dated May 7, 
appointment. ${ }^{10}$ The petitioners also sought a declaratory judgment denying the Lieutenant Governor's power to act as Governor during the Governor's absence from the state unless certain conditions were satisfied. ${ }^{11}$ Finally, in the event the court found that Lieutenant Governor Curb had acted within the scope of his powers in making the Arabian appointment, petitioners sought a declaration that the Governor's withdrawal of that appointment was valid and effective. ${ }^{12}$

On May 21 the Commission on the Governorship filed with the supreme court a "Petition for Determination of Questions under Section 10 of Article V of the California Constitution." The commission requested the court to determine whether the constitution authorized the Lieutenant Governor, during the Governor's absence from the state, to make appointınents to the courts of appeal, and to "set forth standards which may be apphed to facts and circumstances which may foreseeably arise in the future."13

\section{B. The Court's Opinion}

\section{1. "Absence from the State"}

The controversy in Brown centered around the interpretation to be given article V, section 10 of the California Constitution. Article V, section 10 provides:

The Lieutenant Governor shall become Governor when a vacancy occurs in the office of Governor.

The Lieutenant Governor shall act as Governor during the impeachment, absence from the State, or other temporary disability of the Governor or of a Governor-elect who fails to take office.

The Legislature shall provide an order of precedence after the Lieutenant Governor for succession to the office of Governor and for the temporary exercise of the Governor's functions.

1979. Art. V, $\S 10$ of the California Constitution provides the supreme court with exclusive jurisdiction to determine all questions arising under that section.

10. 26 Cal. 3d at 114, 603 P.2d at 1360, 160 Cal. Rptr. at 763.

11. Petition for Writs of Mandate and Prohibition and for Declaratory Relief, supra note 9, at 12-13. Specifically, the Governor maintained that a petition by the Commission on the Governorship and a supreme court determination of disability were required before a Lieutenant Governor could act.

12. $26 \mathrm{Cal}$. 3d at 115, 603 P.2d at 1361, 160 Cal. Rptr. at 763. Lieutenant Governor Curb took action inconsistent with Governor Brown's wishes on one other occasion. On May 16, 1979, during Brown's absence from the state, Curb issued an Executive Order lowering atmospheric air quality restrictions imposed upon oil refiners. Governor Brown contended that Curb's issuance of the order was illegal, and thus did not bother to revoke it, instead issuing his own similar order shortly afterwards. See Los Angeles Times, May 17, 1979, § 1, at 3. The legal questions raised by Curb's issuance of the Executive Order coincide with those raised by the Arabian appointment; the court in deciding Brown resolved the executive order controversy as well. The discussion in this Note, therefore, will focus exclusively on the Arabian appointment controversy.

13. $26 \mathrm{Cal} .3 \mathrm{~d}$ at $115,603 \mathrm{P} .2 \mathrm{~d}$ at $1361,160 \mathrm{Cal}$. Rptr. at 763. 
The Supreme Court has exclusive jurisdiction to determine all questions arising under this section. Standing to raise questions of vacancy or temporary disability is vested exclusively in a body provided by statute. ${ }^{14}$

The body accorded exclusive standing to raise questions of vacancy or temporary disability is the Commission on the Governorship. ${ }^{15}$

After deciding that it had jurisdiction to consider the issues in Brown, and that petitioners had standing to raise those issues, ${ }^{16}$ the court considered Governor Brown's contention that the Lieutenant Governor had no gubernatorial power at the time of the Arabian appointınent. Brown noted that only the Commission on the Governorship may raise questions concerning a Governor's disability, and that only the supreme court may resolve such questions. Therefore, he argued, gubernatorial power cannot pass to a Lieutenant Governor when a Governor is absent from the state until the commission petitions the supreme court and the court determines that the absence constitutes a temporary disability. ${ }^{17}$

14. CAL. CONST. art. V, \& 10 (emphasis added).

15. CAL. Gov'T CODE $\S \S 12070-12076$ (West Supp. 1979). The Commission is composed of the President pro Tempore of the Senate, the Speaker of the Assembly, the President of the University of California, the Chancellor of the California State Colleges, and the State Director of Finance, and has "exclusive authority to petition the Supreme Court to decide any questions relating to the existence of a temporary disability of the Governor." Id. \$ 12072.

16. The court held that jurisdiction rested on the clear and unambiguous language of art. $\mathrm{V}$, \& 10: "The Supreme Court has exclusive jurisdiction to determine all questions arising under this section." Since the controversy im Brown involved an interpretation of the phrase "absence from the State," jurisdiction over the question lay exclusively in the supreme court. $26 \mathrm{Cal} .3 \mathrm{~d}$ at 115 , 603 P.2d at 1361, 160 Cal. Rptr. at 763.

Standing was more troublesome, particularly with respect to Governor Brown's petition. The final paragraph of art. V, $\S 10$ provides that "standing to raise questions of vacancy or temporary disability is vcsted exclusively in a body provided for by statute," the Commission on the Governorship. CAL. Gov't CODE $\$ \S 12070-12076$ (West Supp. 1979).

Based on the language of art. $\mathrm{V}, \S 10$, the court concluded that only the Commission on the Governorship could raise questions relating to vacancy or temporary disability before the supreme court. $26 \mathrm{Cal} .3 \mathrm{~d}$ at $115,603 \mathrm{P} .2 \mathrm{~d}$ at $1361,160 \mathrm{Cal}$. Rptr. at 764 . The court also held that an absence from the state is a temporary disability within the meaning of art. $\mathrm{V}, \S 10$, because $\S 10$ is structured so as to place the phrase "or other temporary disability of the Governor" (emphasis added) inmediately after the statement that impeachment and absence from the state are two occasions upon which the Lieutenant Governor is to act as Governor. Thus, the court considered it "obvious that absence from the state is a temporary disability within the meaning of art. V, \$ 10." Id. at 115 n.4, 603 P.2d at 1361 n.4, 160 Cal. Rptr. at 764 n.4.

Although the court held that only the commission had standing to raise questions relating to art. V, $\S 10$, it also held that the issues presented by the Governor's petition could be considered. The court reasoned that "once the question is properly raised . . . nothing in the section's wording or aims prevents us from concurrently considering pleadings and argunents from interested persons on matters within the scope of the Commission's question." Id. at 115-16, 603 P.2d at 1361, 160 Cal. Rptr. at 764.

17. $26 \mathrm{Cal} .3 \mathrm{~d}$ at 116-17, 603 P.2d at 1362, 160 Cal. Rptr. at 764-65. See also Petitioner's exhibit 6, Memorandum to the Chairperson of the Commission on Judicial Appointments, submitted by Morrison \& Foerster, at 6-12 (April 28, 1979). 
The court refused, however, to impose Governor Brown's suggested procedure. It reasoned that the requirement of a petition and supreme court determination of disabihity "would contravene the purpose of article $\mathrm{V}$, section 10 , to prevent gaps in the availabihty and continuity of the executive power." 18 Furthermore, the court believed that Brown's suggested procedure would require it to render advisory opinions-which are prohibited by the Cahfornia Constitution. ${ }^{19}$ The court concluded that the Lieutenant Governor inust initially interpret the law prescribing his executive duties. The role of the supreme court is limited to the resolution of controversies arising over the Lieutenant Governor's decision im specific instances. ${ }^{20}$

The supreme court then turned to the question of whether a physically absent Governor is "absent from the State" withm the ineaning of article V, section 10. Governor Brown argued that the Lieutenant Governor could assume gubernatorial powers upon a Governor's absence froin the state only if the Governor was unable to conduct urgent state business. ${ }^{21}$ The court held, however, that the mere physical absence of the Governor from California confers full gubernatorial powers on the physically present Lieutenant Governor.

In support of its holding, the court noted the absence of hitigation challenging the proposition that a Governor's physical absence from Cahforma confers full gubernatorial power on the Lieutenant Governor ${ }^{22}$ - even though in the past sixteen years alone hundreds of gubernatorial actions were taken by the Lieutenant Governor in the Governor's absence. ${ }^{23}$ The court reasoned that "the unquestioned acceptance of these exercises of gubernatorial power is evidence of a settled conteinporaneous construction deserving of great weight."24 The court also stated that the language of sections 12002 and 12058 of the Government Code $^{25}$ leave no room "for a watered down 'effective' absence or any other concept whereby an acting governor could discharge

18. 26 Cal. $3 d$ at 117,603 P.2d at 1362,160 Cal. Rptr. at 764 .

19. Id.

20. Id.

21. See note 17 supra.

22. 26 Cal. 3d at 118, 603 P.2d at 1363, 160 Cal. Rptr. at 765 .

23. Id. at $118 \mathrm{n} .6,603$ P.2d at 1363 n.6, 160 Cal. Rptr. at 765 n.6.

24. Id. at 120,603 P.2d at 1364,160 Cal. Rptr. at 766 .

25. Government Code $\S 12002$ provides that "[e]very law of this state relating to the powers and duties of the Governor and to acts and duties to be performed by others toward him extends to the person performing for the time being the duties of Governor." CAL. Gov'T CODE $§ 12002$ (West 1971).

Government Code $\S 12058$ provides, in pertinent part: "In case of impeachment of the Governor or officer acting as Governor, his absence from the state, or his other temporary disability to discharge the powers and duties of office, then the powers and duties of the Office of Governor devolve upon the same person as in the case of vacancy in the Office of Governor, but only until the disability shall cease." Id. $\S 12058$ (West Supp. 1980). 
some but not all of the duties of the governor im his absence."26

The court then considered cases from other jurisdiction ${ }^{27}$ that support an "effective absence" interpretation of "absence froin the State." Rejecting these cases as improperly decided, the court argued that any physical absence by a Governor might create a need for emergency action by an acting Governor. ${ }^{28}$

Finally, the court addressed Governor Brown's contention that improved systeins of cominunication and transportation obviate the need for a hiteral interpretation of "absence from the State." The Governor argued that he retains his ability to direct state affairs even when he is thousands of miles away. The court noted, however, that the Constitution Revision Commission could have changed the language of article $\mathrm{V}$, section 10 in 1966 to reflect modern conditions but chose not to do so. The court was thus "not persuaded that time or technology compels such a change by judicial fiat." 29

\section{Revocation of the Arabian Appointment}

Having concluded that Lieutenant Governor Curb acted within the scope of his powers in appointing Judge Arabian as presiding justice of the court of appeal, the court turned to the remaining question, whether Governor Brown's revocation of the Arabian appointment upon his return to the state was valid. Curb argued that the appointive power was exhausted once he submitted the Arabian appointınent to the Commission on Judicial Appointments, and that therefore the appointment could not be revoked by Brown. ${ }^{30}$

The court stated that the Governor's power to revoke or withdraw an appointment terminates when the last act necessary to the appoint-

26. 26 Cal. $3 \mathrm{~d}$ at 120,603 P.2d at 1364,160 Cal. Rptr. at 766 .

27. Id. at 119 n.7, 603 P.2d at 1363 n.7, 160 Cal. Rptr. at 766 n.7; Watkins v. Mooney, 114 Ky. 646, 71 S.W. 622 (1903); Cytacki v. Buscko, 226 Mich. 524, 197 N.W. 1021 (1924); Mayor of Detroit v. Moran, 46 Mich. 213, 9 N.W. 252 (1881); Sawyer v. First Judicial District Court, 82 Nev. 53, 410 P.2d 748 (1966); Gelinas v. Fugere, 55 R.1. 225, 180 A. 346 (1935); State ex rel Olson v. Lahiff, 146 Wis. 490,131 N.W. 824 (1911).

28. 26 Cal. 3d at 119,603 P.2d at 1363, 160 Cal. Rptr. at 766.

29. Id. at 123-30, 630 P.2d at 1366-70, 160 Cal. Rptr. at 768-73. Justice Newman's concurring opinion agreed with the majority's result in the case presented, but reached a different conclusion on the meaning of "absence from the State." Focusing on the words "or other temporary disability" in art. V, $\S 10$, Justice Newman argued that the Constitution Revision Commission counsel erred in concluding that absence, though not necessarily constituting a factual inability, nevertheless legally disables a Governor from acting. He concluded that, in light of modern conditions of travel and communication, absence is not necessarily an inability, and so should not disable a Governor from acting from outside the state. Newman reached the saine result as the majority only because he agreed with its conclusion that the Governor could vahilly withdraw the Arabian appointment.

30. Id. at 121, 630 P.2d at 1364,160 Cal. Rptr. at 767. 
ment process is completed. ${ }^{31}$ The transmittal of the appointee's name to the Commission on Judicial Appintments, however, does not constitute the final act. ${ }^{32}$ An appointment to the court of appeal is effective only "when confirmed by the Commission on Judicial Appointments," and "filed in writing with the Secretary of State." 33 Accordingly, since Governor Brown withdrew the Arabian appoimtment prior to confirmation by the commission, the court held that the withdrawal was valid.

The court offered several reasons to support its conclusion. First, it noted that past Governors had withdrawn appointments from commission consideration without challenge of their right to do so. ${ }^{34} \mathrm{Sec}-$ ond, to permit withdrawal prior to confirmation accords with the purposes for which the commission was created, i.e., to assure a thorough consideration of a candidate's qualifications. ${ }^{35}$ Third, the objection that withdrawal constitutes removal from office is invalid because prior to commission confirmation the appointee is vested with no right of office. ${ }^{36}$ Finally, the court stated that its position was similar to that taken in other states. ${ }^{37}$

II

\section{ANALYSIS}

\section{A. Determining the Existence of Disability}

The first task the supreme court undertook was to determine the procedural framework that article V, section 10 of the Cahfornia Constitution creates im cases involving a Governor's alleged disability. Section 10 states that "the Lieutenant Governor shall act as Governor during the impeachment, absence from the State, or other teinporary

31. Id.

32. CAL. Const. art. VI, § 16(d).

33. CAL. Gov't CODE $\S 68121$ (West 1976).

34. $26 \mathrm{Cal}$. 3d at 122, 603 P.2d at 1365, 160 Cal. Rptr. at 768. Chief Justice Gibson, while testifying before the Judiciary Committee on July 14, 1958, stated that past Governors had withdrawn appointments pending before the Qualifications Commission (the former name of the Commission on Judicial Appointments) after having consulted with menbers of the commission and before making the appointments public. PARTIAL RePORT OF THE JOINT JUDICIARY COMMITTEE ON THE ADMINISTRATION OF JUSTICE 38-39, 2 Appendix to the Journal of the Senate 37 (1959).

35. $26 \mathrm{Cal} .3 \mathrm{~d}$ at $122,603 \mathrm{P} .2 \mathrm{~d}$ at 1365,160 Cal. Rptr. at 768.

36. Id.

37. Id. An example of this general rule is found in the case of McCliesney v. Sampson, 232 Ky. 395, 23 S.W.2d 584 (1930): "wliere the nomination must be confirmed before the officer can take the office or exercise any of its functions, the power of removal is not involved and nominations inay be clianged at the will of the executive until title to the office is vested." $I d$. at 401,23 S.W.2d at 587. The Brown court warned in a footnote, however, that it was not deciding at what point the appointment of a judge not subject to confirmation by the Commission on Judicial Appointments becomes irrevocable. $26 \mathrm{Cal} .3 \mathrm{~d}$ at $122 \mathrm{n} .9,603 \mathrm{P} .2 \mathrm{~d}$ at $1365 \mathrm{n} .9,160 \mathrm{Cal}$. Rptr. at 768 n.9. 
disability of the Governor." It also provides that the supreme court "shall have exclusive jurisdiction to determme all questions arising under this section," and confers exclusive standing to raise such questions upon the Commission on the Governorship.

Governor Brown suggested that article V, section 10 establishes a specific procedure that must be followed before a Lieutenant Governor may exercise gubernatorial power during a Governor's absence from the state. Specifically, the Lieutenant Governor may not assuine such powers until the Commission on the Governorship petitions the supreme court and the court determines that a temporary disability exists. ${ }^{38}$

Because Lieutenant Governor Curb failed to follow this procedure when the Governor was absent from California, Brown concluded, the appointınent of Judge Arabian to the court of appeal was inade without legal authority and was therefore invalid.

The court rejected this argument on the ground that the procedure advocated by the Governor would require the court to render advisory opinions. ${ }^{39}$ It explained that

the Constitution charges us only with determining "questions" of temporary disability, not with giving advisory opinions in the absence of dispute. The Lieutenant Governor-like any public officer with executive duties-must apply and, if necessary, interpret the law prescribing those duties as found in the Constitution, legislation, and authoritative decision. Our role is to resolve controversies as to imterpretation, not to dictate initial formulations. ${ }^{40}$

The court therefore decided that a Lieutenant Governor inay exercise gubernatorial power in the Governor's absence without prior judicial authorization.

The court reached the right conclusion-but for the wrong reasons. In so doing it may have impaired the ability of article $\mathrm{V}$, section 10 to provide an impartial means for resolving genuine questions of temporary disability.

The court's reasoning was faulty in two respects. The court erred first in assuming that the procedure advocated by the Governor would require it to render an "advisory opimon in the absence of dispute." It then compounded its error by failing to recognize that article V, section 10 was purposely designed to elicit just such an advance opinion, and

38. 26 Cal. $3 \mathrm{~d}$ at $116-17,603 \mathrm{P} .2 \mathrm{~d}$ at $1362,160 \mathrm{Cal}$. Rptr. at 764. A similar procedure would presumably be required in order for the Governor, upon his return, to reassume power, since Government Code $\S 12073$ provides that only the Commission on the Governorship has standing to petition the supreme court to decide questions relating to the termination of a temporary disability of the Governor.

39. Id.

40. Id. 
thus avoid potentially paralyzing disputes between a Governor and Lieutenant Governor.

An advisory opinion is one in which the parties "seek a judicial declaration on a question of law, though no actual dispute or controversy ever existed between them requiring such a declaration for its determination." 41 Courts in California have consistently refused to render advisory opinions.

Situations involving the alleged disability of a Governor, however, do not occur in the absence of dispute; indeed, judicial intervention is needed precisely because of disagreenent as to who is the lawful chief executive of the state. The court's assertion in Brown that it is the Lieutenant Governor's responsibility to act in accordance with the constitution as he interprets it ignores the fact that his actions inay, if taken without authority, be illegal, thus subjecting him to the possibility of personal liability. Thus, a justiciable controversy clearly exists when the Lieutenant Governor challenges the Governor's ability to hold office.

A prior decision by the court would seem to support this conclusion. In Golden Gate Bridge and Highway District v. Felt, ${ }^{42}$ the Secretary of the Board of Directors of the Golden Gate Bridge and Highway District refused to sign certain bonds that the district proposed to issue, contending that the bonds were an unconstitutional exercise of taxing authority by an appointive body. The board sued for a writ of mandate to coinpel the Secretary to sign the bonds. Several taxpayers intervened as ainicus curiae, arguing that no justiciable controversy existed because the Secretary apparently favored the issuance of the bonds and refused to sign thein only because of his belief that they unight be unlawful.

The court in Golden Gate Bridge District rejected the taxpayers' argument. As a public official holding office under the constitution, the Secretary was bound to support the constitution and the laws of California. He possessed a good faith belief that he could not act without a significant risk of violating the constitution. The court held that, were his contention sound,

and he were forced to sign, he would be acting in violation of his public duty . . . He is not bound to take a step which might conceivably involve a personal liability on his part in the event of a subsequent judicial declaration of unconstitutionality of the act. . . . A genuine controversy existed, therefore, between petitioner and respondent as to matters vitally affecting the duties and perhaps the liabilities of the latter . . . . Under these circumstances this court can properly consider

41. 2 Witkin, California Procedure, Actions $\S 38$ (1970).

42. 214 Cal. 308,5 P.2d 585 (1931). 
the petition and adjudicate the issues raised therein. ${ }^{43}$

A Lieutenant Governor uncertain as to whether a Governor is disabled is in the same situation as the Secretary in Golden Gate Bridge District. By taking action, he might conceivably subject himself to personal liability for the effects of his acts should the court subsequently declare that the Governor was not legally disabled. Furthermore, none of the elements that make courts reluctant to decide cases in advance of controversy are present. A controversy-concerning the Governor's purported disability-does exist. The issues are cast in as concrete a form as they will ever be. Indeed, requiring the Lieutenant Governor to act before the alleged disability can be adjudicated will not clarify the circumstances surrounding the disability. Such a requirement would, in fact, serve only to heighten the adverse consequences, both to the state and to the acting Governor, which might result from an incorrect determination by the Lieutenant Governor that the Governor was disabled.

The court thus erred in asserting that the petitioning procedure advocated by Governor Brown would result in advisory opmions. Nevertheless, the court correctly decided that such a procedure was inappropriate under the circumstances before it, albeit for the wrong reasons.

Article V, section 10 gives the suprenne court exclusive jurisdiction to determine questions pertaining to disability. The Constitution Revision Commission drafted this provision to ensure that disputes arising over a Governor's purported disability would be swiftly settled. Rather than enumerating all possible disabilities, the commission employed the vague term "other temporary disability" as a trigger for the court's jurisdiction. ${ }^{44}$ This would permit the consideration of unforeseen disabilities. ${ }^{45}$ Thus, the commission intended that the court render a deci-

43. Id. at 314,5 P.2d at 590 .

44. Assembly Interim Committee on Constitutional Amendments, Meeting of the Full Committee on Constitutional Revision of Articles V \& VI, at 23, 31 (1966). When asked if there should be limitations on the supreme court's authority to determine the existence of a disability, the committee counsel responded that "the [previous] spelling out of certain limitations and describing specific situations left the body which has to make this ultimate detcrmimation, a very difficult determination, really insufficient tools to do it with." $I d$. at 23 .

45. As Barry Keene, counsel to the Constitution Revision Commission, explained to the Assembly Interim Committee on Constitutional Amendments in 1966, the proposed amendment was designed to give the supreme court

authority to interpret the principles reflected in this section in unforeseen situations. One of the great fears in the existing Constitution is that there are situations-each situation is described and there inay be some situations that the framers just never thought about, and certainly we can't predict every contingency in every occurrence. There [sic] we provided proposed section [10] on the Supreme Court. They will have the jurisdiction to decide these things once and for all and hopefully free of the political infiuences that might affect other offices. Id. at 20 (emphasis added). 
sion as to the Governor's purported disability before any transfer of power to the Lieutenant Governor took place.

In drafting section 10, however, the Constitution Revision Commission did specify two particular situations constituting disability: impeachment and absence from the state. The authors intended that both impeachment and absence from the state be per se disabilities, automatically transferring gubernatorial power from the Governor to the Lieutenant Governor without prior review by the supreme court.

In other words, the section 10 petitioning procedure, whicl Governor Brown wanted to apply in this context, was not designed to apply in cases of a Governor's absence from the state. Section 10, as noted earlier, requires use of the procedure in situations involving questions of teinporary disability. The legal effect of a Governor's absence from California, however, does not present a question-absence from the state autoinatically transfers gubernatorial power. Where the parties do not dispute the fact of a Governor's absence, there is simply no question to be decided by the court.

The court's conclusion-that the petitioning procedure does not apply in cases of absence froin the state-is thus correct. Its reasoning-that the procedure would lead to advisory opinions-is clearly erroneous. Instead, the court's conclusion is supported by a legislative history which suggests that gubernatorial power automatically transfers to a Lieutenant Governor, without supreme court review, whenever the Governor is absent from the state. The court's refusal to apply the article $\mathrm{V}$, section 10 petitioning process to controversies concerning a Governor's absence from the state is sensible. Application of that process in such situations would be highly impractical.

Unlike physical and mental disabilities, absence from the state occurs witl soine regularity, as the Governor often must travel outside California on state business. Were a Lieutenant Governor required to seek a petition from the Commission on the Governorship and a subsequent supreme court determination that a disability existed every time the Governor left the state, the Lieutenant Governor's ability to act quickly in an einergency would be extremely restricted. Section 10 was enacted to prevent "gaps in the availability and continuity of the executive power." ${ }^{46}$ To apply the petitioning process to a Governor's absence from the state would effectively contravene that purpose.

The court's "advisory opinion" reasoning raises troublesome questions when applied to the kinds of circumstances in which the petitioning process was intended to operate. The court has, in fact, thrown the legitimacy of the procedure into considerable doubt. Suppose, for ex-

46. 26 Cal. 3d at 117, 603 P.2d at 1362, 160 Cal. Rptr. at 764. 
ample, that the Governor suffers a partial nervous breakdown. The court's opinion fails to detail just what action a Lieutenant Governor must take in this situation to make the controversy over the Governor's disability justiciable.

The court might have meant that the Lieutenant Governor would have to take some sort of gubernatorial action, thus provoking a political controversy with the Governor, before a legal controversy sufficient to invoke the court's jurisdiction would exist. Requiring this sort of controversy, however, creates precisely the kind of political chaos that article $\mathrm{V}$, section 10 is supposed to prevent. It forces the state to undergo the trauma and confusion of separate and possibly inconsistent actions by two individuals, each claiming to be Governor. The petitioning process, by preventing the devolution of power to the Lieutenant Governor until the supreme court determines that a disability exists, would prevent this confusion.

On the other hand, the court might have meant that a Lieutenant Governor need only raise a colorable claim of disabihty in order for a justiciable controversy to exist. This would force the Lieutenant Governor to invoke the procedure prior to his exercise of gubernatorial power, thereby avoiding a serious political controversy.

The problem remains, however, that the court's opinion in Brown offers hittle guidance on this important issue. Clarification by the court is therefore necessary.

\section{B. The "Effective Absence" Argument}

The court then had to settle the meaning of section 10's "absence from the State" clause. Governor Brown argued that the court should adopt an "effective absence" test. Under this test, gubernatorial power does not pass to the Lieutenant Governor during a Governor's absence unless the Governor is unable to conduct immediately-necessary state business-i.e., the Lieutenant Governor may exercise power only when there is a sigmificant need for a particular act by a physically present official. ${ }^{47}$

Courts in several other jurisdictions have recognized the desirability of an effective absence rnle in interpreting constitutional provisions similar to California's. ${ }^{48}$ These courts did not define absence literally,

47. 26 Cal. $3 d$ at 117,603 P.2d at 1362,160 Cal. Rptr. at 764 .

48. Watkins v. Mooney, 114 Ky. 646, 71 S.W. 622 (1903); State ex rel Warmoth v. Graham, 26 La. Ann. 568 (1874); Cytacki v. Buscko, 226 Mich. 524, 197 N.W. 1021 (1924); Mayor of Detroit v. Moran, 46 Micl. 213, 9 N.W. 252 (1881); In re An Act Concerning Alcoholic Beverages, 130 N.J.L. 123, 31 A.2d 837 (1943); Sawyer v. First Judicial Dist., 82 Nev. 53, 410 P.2d 748 (1966); Gelinas v. Fugere, 55 R.I. 225, 180 A. 346 (1935); State ex rel Olson v. Lahiff, 146 Wis. 490, 131 N.W. 824 (1911). 
and were therefore able to invalidate actions taken by an acting Governor that were contrary to the policies of the absent Governor. ${ }^{49}$

The most recent out-of-state case was the Nevada Supreme Court's decision in Sawyer v. First Judicial District. ${ }^{50}$ The court balanced competing policy concerns - the right of the citizenry to have all powers and duties entrusted to a public office fulfilled, along with a disdain for government by absentee officials, against the citizens' right to have the policies of the individual they placed in office effectuated, ${ }^{51}$ and concluded that an "effective absence" test best accommodated these policy concerns. Such a test would permit a successor official to act in a Governor's absence when action was necessary, and yet would prevent that official from acting contrary to the Governor's wishes when no emergency requiring executive action existed. ${ }^{52}$

The Brown court, however, interpreted "absence froin the State" as referring to literal, plysical absence. ${ }^{53}$ The majority argued that the effective absence test has a conceptual difficulty: virtually any physical absence of the Governor inay create a need for action by an acting Governor, at least to deal with emergencies. Governor Brown did not claim any power to act from outside the state's boundaries, nor had any of his predecessors ever made such a claim. The court therefore concluded that because a pliysically absent Governor cannot act, the overridimg purpose of avoiding a hiatus in the availability of executive power requires that the sole and entire power to act as Governor be automatically transferred to a Lieutenant Governor who is physically within the state. ${ }^{54}$

There are two flaws in this reasoning. First, the court assumed that a Governor may not act from outside the state. Under a strict absence rule this conclusion in justified, since a contrary mterpretation would permit two individuals - the absent Governor and the acting Governor to whom power would have accrued by the Governor's absence- to act as chief executive of the state simultaneously. Under an effective absence rule, however, an absent Governor might very well

49. The cases dealing with effective absence are discussed in Lurvey, Absent Officials: No Carte Blanche for Successors, 15 J. PuB. L. 324 (1966).

50. 82 Nev. 53, 410 P.2d 748 (1966). In Sawyer, the issue was whether the Lieutenant Governor could impanel a special grand jury to investigate corruption in the State Highway DepartInent during the Governor's five hour absence from the State. The Nevada constitution provides that in case of the Governor's absence from the state, the powers and duties of the office shall devolve upon the Lieutenant Governor for the reinainder of the term or until the Governor's disability ceases. NEv. CoNsT. art. V, \& 18.

51. $82 \mathrm{Nev}$. at 57,410 P.2d at 750 .

52. Id.

53. $26 \mathrm{Cal}$. 3d at 117, 603 P.2d at 1362,160 Cal. Rptr. at 764.

54. $26 \mathrm{Cal}$. 3d at 119, $603 \mathrm{P.2d}$ at 1363, $160 \mathrm{Cal}$. Rptr. at 766. 
act while out of the state. Certainly neither logic nor policy require a contrary result.

Second, the court misunderstood the effective absence approach. The effective absence cases do not prohibit a Lieutenant Governor from ever actimg as Governor during a Governor's absence: they only require that the Lieutenant Governor's actions be necessary, both in terins of the nature and gravity of the situation calling for action and the time sucli action was required. ${ }^{55}$ Consequently, even granting the Brown court's assumption that an effective absence rule would not permit a Governor to act while outside the state, such a rule would not lead to the risk of "a hiatus in the availability of executive power" in situations where executive power is truly needed.

A literal absence test may have been appropriate when the words "absence from the State" were inserted into the California Constitution 130 years ago. Facilities of communication and transportation were poor, and an absent Governor could not easily remain in contact with California. ${ }^{56}$ It was thus of paramount importance that gubernatorial power be transferred to an officer present within the state.

The need for a literal absence test, however, eroded as communications and transportation improved. In almost all situations today, an absent Governor can be reached within mimutes by telephone and can, if necessary, return to the state within a few hours. Even where rapid return is impossible-when the Governor is, say, in Africa-the Governor can still make decisions outside California and communicate tliem back to the state. As Justice Newman's concurring opinion noted, telecopiers, special word processors, talking typewriters, and instant information retrieval systems are available, none of which are affected by state or international boundaries. ${ }^{57}$

Furthernore, a literal absence test has disadvantages. Governors must often attend to business outside of the state. Were a Governor reluctant to leave the state out of fear that a Lieutenant Governor might act in ways damaging to the Governor's policies, the Governor's ability to promote important state interests might be adversely affected. ${ }^{58}$ As the occasion for travel increases, therefore, it is critical to develop a rule of succession that enables Governors to travel without

55. 26 Cal. 3d at 117,603 P.2d at 1362,160 Cal. Rptr. at 764 .

56. On the effect of improved transportation and communications on the interpretation of absence-froin-the-state provisions, see Markham v. Cornell, 136 Kan. 884, 891-92, 18 P.2d 158, 163 (1933).

57. $26 \mathrm{Cal}$. 3d at 124, 603 P.2d at 1367, 160 Cal. Rptr. at 769 (Newntan, J., concurring).

58. Governor Brown, for example, was, at the time of the Arabian appoimtment, testifying in Washington, D.C. before the Senate Committee on Energy and Natural Resources, in an attempt to obtain higher allocations of gasoline for California. 
fear of disruptive acts by Lieutenant Governors, and yet enables the Lieutenant Governor to act should the need arise.

Despite the court's flawed reasoning and its unpersuasive policy arguments in favor of the literal absence approach, it reached the only constitutionally permissible result. The legislative history of the 1966 ainendinents to article $\mathrm{V}$ clearly indicates that section 10 was not intended to be an effective absence provision. ${ }^{59}$ Indeed, the legislative counsel to the Constitution Revision Committee explained in testimony before the Assembly Interim Committee on Constitutional Amendinents that absence from the state is a "legal" disability mandated by the constitution, and that the facts surrounding a particular absence have no relevance to a Lieutenant Governor's succession to the duties of the governorship for the period of the absence. ${ }^{60}$ Nor have the courts ever interpreted section 10 as anything but a literal absence provision.

Conteinporaneous construction of the phrase "absence from the State" by public officials also justified the outcome in Brown. Just a year earlier, in State of South Dakota $v$. Brown ${ }^{61}$ the court held that "the conteinporaneous administrative construction of an enactment by those charged with its enforcement and interpretation is entitled to great weight, and courts will not depart from such construction unless it is clearly erroneous or unauthorized."62 Officials had always interpreted "absence from the State" as a literal absence provision. ${ }^{63}$ The court noted that "in the past sixteen years more than 1,400 gubernatorial actions (proclamations, executive orders, pardons, and signing of legislation) liave been taken by an acting governor while the Governor was physically absent from the state" 64 without any challenge.

The supreme court thus correctly concluded that "constitutional and legislative history, contemporaneous interpretation and historical practice ... support the Lieutenant Governor's position" that the

59. One legislator questioned whether disability was the correct word to be used in connection with the absence of the Governor from the state, contending that disability connotes the innate physicial or inental inabihty to perform the duties of the office. The Committee Counsel responded that:

Yes, it's a disability because we define it as such in the section. . . . ITJ Commission felt that if the Constitution should prohibit the Governor from acting then it should be classified as a disability. It is not an inability. The Governor could be soine place outside the state and be very capable of performing his duties by a long distance telephone. He would be legally disabled from doing so. Disability is more accurate.

Id. at 33-34 (emphasis added).

60. Id.

61. 20 Cal. 3d 765, 76 P.2d 473, 144 Cal. Rptr. 758 (1978).

62. Id. at 777, quoting from City of Los Angeles v. Rancho Hoines, Inc., 40 Cal. 2d 764, 770-

71, 256 P.2d 305, 308 (1953).

63. 26 Cal. $3 \mathrm{~d}$ at 118,603 P.2d at $1362-63,160$ Cal. Rptr. at 765 .

64. Id. at 118 n.6, 603 P.2d at 1363 n.6, 160 Cal. Rptr. at 765 n.6. 
Governor's physical absence automatically transfers gubernatorial power to the Lieutenant Governor. ${ }^{65}$ The court could not have appropriately deviated from this interpretation of "absence from the State." Constitutional language must be accorded a stricter construction than statutory language, for the constitution, " unlike the acts of the legislature, owes its whole force and authority to its ratification by the people; and they judged of it by the meaning apparent on its face according to the general use of the words employed, where they do not appear to have been used in a legal or technical sense." "66 This rule has particular force in California, where revision of the constitution is undertaken relatively frequently.

\section{Withdrawal of a Judicial Appointment}

The parties in Brown agreed that the power to withdraw an appoimtment ceases when the last act necessary to the appointment is completed. ${ }^{67}$ Their principal point of disagreement was over what constituted the final act. The Lieutenant Governor contended that the Governor's submission of the appointee's naine to the Commission on Judicial Appointments was the final act, since at that time the Governor's role in the appointment process ended. Curb concluded, therefore, that Brown could not withdraw the appointment. In contrast, the Governor claimed that confirmation by the commission was the last act. Brown thus suggested that even if Lieutenant Governor Curb had the power to make the Arabian appointment, Brown's withdrawal of that apointment was valid because it occurred prior to confirmation.

In addressing this issue, the court distinguished between two types of gubernatorial appointments. The first type immediately vests in the

65. Petition for Writs of Mandate and Prohibition, and for Declaratory Rehef, at 15-16.

66. Shay v. Roth, 64 Cal. App. 314, 316-17, 221 P. 967, 968 (2d Dist. 1923), quoting froin City of Pasadena v. Railroad Comm'n, 183 Cal. 532, 192 P. 28 (1920).

67. Marbury v. Madison, 5 U.S. (1 Cranch) 137 (1803), is the leading case. In Marbury, James Madison, President Jefferson's Secretary of State, was held to have a ministerial duty to deliver a commission, signed by outgoing President Adams with the advice and consent of the Senate, to Williain Marbury as Justice of the Peace. Chief Justice Marshall, in his opinion for the Court, wrote:

The last act to be done by the president is the signature of the commission. He has then acted on the advice and consent of the senate to his own nomination. The time for deliberation lias passed. He has decided. His judgment, on the advice and consent of the senate concurring with his nommation, has been made, and the officer is appointed. This appointment is evidenced by an open, nnequivocal act; and being the last act required from the person inakmg it, necessarily excludes the idea of its being, so far as respects the appoimtment, an inchoate and imcomplete transaction. Some point in time must be taken, when the power of the executive over an officer, not removeable at his will, inust cease. That point of time inust be when the constitutional power of appointment has been exercised. And this power has been exercised when the last act, required from the person possessing the power, has been performed. This last act is the signature of the commission.

Id. at 157 . 
appointee all the rights and duties of office. For this type of appointinent, confirmation is a condition subsequent: the confirming body cannot prevent the appointee from taking office, but it can, by subsequently failing to confirm him or her, reinove the appointee. ${ }^{68}$ The second type of appointunent does not become effective until a confirming body acts to approve, or confirm, the appointinent. For this type, confirmation is a condition precedent: the appointee may not assuine any of the duties or privileges of office until confirmed. ${ }^{69}$

The court found that appointinents to the Cahifornia Courts of Appeal are examples of the second type of appoimtment. Article VI, $\S 16(d)$ of the constitution provides that appointments to the appellate courts are "effective when confirmed by the Commission on Judicial Appointments," and Government Code $\$ 68121$ provides that confirmation "is effective when filed in writing with the Secretary of State."70 Accordingly, the court held that Governor Brown's withdrawal of the Arabian appointment was valid because it took place prior to confirmation.

The holding in Brown is not supported by directly apphicable precedent. Nevertheless, cases involving analogous factual situations sustain the result. In Conger $v$. Gilmer,$^{71}$ the Sacramento County Board of Supervisors appointed Conger as Justice of the Peace. Before the clerk issued the certificate of appointment necessary to permit Conger to assume office, however, the board reconsidered its appointment and directed the clerk not to issue the certificate. The board subsequently appointed another person to the position, and Conger filed suit, challenging the board's authority to withdraw his appointenent.

The supreme court upheld the withdrawal, stating that the appointment would not become effective until the clerk issued the certificate of appointment, and that issuance of the certificate was a discretionary act within the board's control. ${ }^{72}$ The court stated that

$[U]$ ntil the last act has been performed the whole matter is in fieri, and

68. The confirming body functions, in effect, with a veto power, enabling it to remove, but not requiring its prior approval to place in office, a gubernatorial nommee. Appointments to the California Water Commission are examples of this type of appointment. CAL. WATER CodE $\S 151$ (West 1971).

69. See, e.g., CAL. Const. art. V1, § 16(d).

70. Seetion 68121 was amended in 1967 to provide that confirmation is "effective when filed" instead of "shall not be effective unless filed." In the absence of any legislative history, it is presumed that this change was intended merely to fix more specifically the precise moment when confirmation becomes effective.

71. 32 Cal. 75 (1867).

72. The court held that the appointinent was similar to the signing of Marbury's commission in Marbury v. Madison, which the United States Supreme Court held to be a discretionary act. Although the Supreme Court had held the issuance of an already signed commission to be a ininisterial act, and therefore not discretionary with the issuing authority, the situation in Conger involved the filling of an elective office by a vacancy appointment, which substituted the issuance 
within the control of the person or persons by whom the appointment is made, and there is nothing to prevent them from changing their minds and appointing some other person than the one first selected. ${ }^{73}$

Consistent with this principal are California cases that have denied a Governor's authority to revoke appointments which had already vested in the appointees the right to assume the responsibilities of office. Thus, in Weatherbee $v$. Cazneau, ${ }^{74}$ the supreme court held that an interim appointment to fill a vacancy in the office of Superintendent of Immigration for the Port of San Francisco could not be withdrawn by the succeeding Governor, ${ }^{75}$ even though the senate had not yet confirmed the appointment, because the appointee had by virtue of the appointment already "qualified and entered upon the duties of the office."76 A like result was reached in People ex rel. Ryder $\nu$. Mizner. ${ }^{77}$ During a legislative recess, the Governor commissioned Mizner to fill a vacancy in the office of gauger of wines and liquors. Several months later, with the legislature again in session, the Governor sought to appoint Ryder to the position, Mizner's naine having never been submitted to the senate for confirmation. The senate confirmed Ryder, but Mizner refused to vacate the office, contending that the Governor's revocation of his appointment was invalid and therefore that no vacancy existed for the Governor to fill. The supreme court found that Mizner's appointment had vested and held that the Governor lacked the authority to revoke it. ${ }^{78}$

Courts in other jurisdictions have followed this reasoning and reached similar results. ${ }^{79}$ Underlying these cases is a common purpose, to prohibit the executive from removing from office an appintee not removable at the will of the executive. ${ }^{80}$ Once the right to assume the

of the commission for the election by the people as the last discretionary act necessary for the appointment to take effect.

73. $32 \mathrm{Cal}$. at 79.

74. 20 Cal. 503 (1862).

75. It should be noted that the cases, in referring to the last act by the appointing authority necessary to the appointment, mean the office of that authority: thus, if one Governor performs that final act, a succeeding Governor may not subsequently withdraw the appoimtment.

76. $20 \mathrm{Cal}$. at 506 .

77. 7 Cal. 5 I9 (1857).

78. Id. at 526 .

79. See, eg., McBride v. Osborn, 59 Ariz. 321, 127 P.2d 134 (1942); McChesney v. Sampson, 232 Ky. 395, 23 S.W.2d 584 (1930); State ex rel. Todd v. Essling, 268 Minn. 151, 128 N.W.2d 307 (1964).

The Arizona Supreme Court's decision in McBride v. Osborn is particularly instructive, since the court held that the Governor could withdraw an appointee at any time prior to the vesting of an appointinent. In reaching that conclusion the court distinguished several cases which held that a Governor could not withdraw an appointment once it was sent to the senate for confirmation, since "the appointment in each [such] case had the effect of vesting the appointee with the office." 59 Ariz. at 327, 127 P.2d at 136.

80. Thus, in McBride the Arizona Supreme Court stated: 
duties and responsibilities of an office vests in an appointee, the executive may not interfere with the appointment. In part this rule ensures that removal powers which are exclusively delegated to the legislative branch or to the voters remain with these bodies. It also is consistent with the pohicy which underlies making an appointunent not reinovable at the will of the executive, i.e., to protect from political interference the peformance of the person holding the office. ${ }^{81}$ Where an appointment permits an appoimtee to begm to exercise the duties of his office immediately, the same considerations apply, and the executive should be prohibited from revoking the appointment.

The court in Brown, then, correctly determined that Governor Brown could withdraw the Arabian appointment up until the time confirmation became effective. Judge Arabian had no legal right to the office until that time. The court's decision softened the practical impact of its finding that Lieutenant Governor Curb had the power to make the appointment in the Governor's absence, but by no means removed the considerable practical problems engendered by that holding.

III

\section{Legislative Resolution of the Problem}

At first glance the possibility of future conflicts between Governors and Lieutenant Governors concerning the power to act during a Governor's absence might seein too shight to inerit further attention. The circumstances which gave rise to the legal controversy in Brown v. Curb were unusual. After the 1978 election, California found itself with a Governor and a Lieutenant Governor from different political parties for the first time in this century. ${ }^{82}$ Though they pledged to work together closely, ${ }^{83}$ Governor Brown and Lieutenant Governor Curb held widely divergent political views and soon disagreed publicly. ${ }^{84}$ In addition, Governor Brown's presidential ambitions further complicated the situation. ${ }^{85}$

[I] $t$ is clear that to have held the governor, or other appointing power, could cancel a (vested) appointment and withdraw the naine of [the] appointee . . . would have given the governor, or other appointing power, the right to reinove froin office when that right did not exist under the law, except after a hearing and for cause.

59 Ariz. at 327,127 P.2d at 136.

81. See, e.g., Humphrey's Executor v. United States, 295 U.S. 602, 624-26 (1935).

82. Los Angeles Times, November 8, 1978, \& 1, at 1 .

83. Id.

84. Id., March 1, 1979, \& 1, at 3.

85. Despite his election promise to devote full energies to governing California, Brown showed increasing interest in the Presidency, and began to leave the state regularly for reasons other than state business. See id, October 21, 1978, \& 2, at 1, 11. Brown's travels were not received favorably by California voters, many of whom perceived him as having neglected his duties within California. Id., March 24, 1979, § 2, at 16. Lieutenant Governor Curb was not unaware of 
Nevertheless, unusual circumstances or not, Brown's literal plrysical absence interpretation of "absence from the State" leaves open the possibility of future problems. Governor Brown's assertion that this interpretation might "unreasonably disrupt the orderly processes of government" ${ }^{16}$ seems reasonable when the actions of the prescnt Lieutenant Governor are considered. Lieutenant Governor Curb had on two occasions taken action during the Governor's absence from the state on official business that was contrary to Brown's announced intentions. ${ }^{87}$ Certainly, Curb's actions did no irreparable damage to the welfare of the state. ${ }^{88}$ But they made state government appear ludicrous, and delayed the filling of a vacancy on the court of appeal.

Additionally, it is not difficult to conceive of situations in which a Lieutenant Governor, by taking irrevocable actions during the Governor's absence, ${ }^{89}$ could severely injure an administration's ability to govern. Even the threat of such action by a "renegade" Lieutenant Governor could be detrimental since it might diminish a Governor's willingness to leave the state on important state business. ${ }^{90}$ Some sort of legislative remedy is thus required.

There are two legitimate, but conflicting policy considerations in this area. On the one hand is the people's right to always have, ready and able to act, a chief executive with full gubernatorial power. ${ }^{91}$ On

this sentiment. Indeed, his justification for appointing Judge Arabian relied in part on the assumption that the people elected Curb as Lieutenant Governor to curtail the travel Brown's ambitions would almost certainly entail. Answer to Petition for Writs of Mandate and Prohibition and for Declaratory Relief, and Answer for Petition for Determination of Questions Under Section 10 of Article $V$ of the California Constitution: Memorandum of Points and Authorities, Exhibit B, at 2-3. One ironic note is that Lieutenant Governor Curb made the Arabian appointment not while Governor Brown was out of state on a campaign trip but while Brown was in Washington, D.C. on state business. Petition for Writs of Mandate and Prohibition, and for Declaratory Relief, supra note 9 , at 5 .

86. Id. at 43.

87. The Arabian appointment and the relaxation of restrictions on atmospheric lead content. See note 12, supra.

88. That no irremediable liarm oceurred, in the sense that no judge unacceptable to the duly elected Governor ascended to the court of appeal, was due only to the Governor's ability to withdraw the appointment before its confirmation by the Commission on Judicial Appointments. Obstruction of the Governor's policies rcgarding atmospheric restrictions on lead was avoided largely because oil companies ignored the Lieutenant Governor's order. See Los Angeles Times, May 17, $1979, \S 1$, at 7 , col. 1 .

89. E.g., Pardons of convicted offenders, once delivered, are generally considered irrevocable. See 59 AM. Jur. 2d Parole and Pardon $\$ 17$ (1971). Also, many appointments do not require senatorial confirmation, e.g., to the State Bar Disciplinary Board and to the State Bar Board of Control, and once made, are irrevocable by the Governor.

90. Effective state government could also be hindered if a Governor attempted to circumvent an anticipated act by the Lieutenant Governor. For example, a Governor intending to leave the state for a time might hurry to take actions-such as signing or vetoing legislation or making irrevocable appointments-whicl would be better made after a more careful, thorough reflection, a possibility as potentially injurious as delay in making such decisions.

91. The purpose of art. V, $\S 10$, said the court in Brown, was "to prevent gaps in the availa- 
the other hand is the people's "equal right to realize the unintruded policies of the individual they placed in [the Governor's] office."92 Adherence to the literal absence approach furthers the first of these goals: a Lieutenant Governor immediately and undeniably ${ }^{93}$ assumes complete control upon the Governor's departure and relinquishes that control upon the Governor's return. As in the present case, however, this approach soinetimes obstructs implementation of the departed Governor's policies.

Two general ways to overcome this problem exist. The first is to change the rule pertaining to succession to office in order to prevent a Lieutenant Governor from actimg as Governor except when the public welfare requires it. Thus the legislature could adopt the "effective absence" rule. The traditional "effective absence" rule, however, has two defects. First, it depends on a determination as to when and whether an action is "necessary." "Necessary," of course, is as relative a term as can be found, and the potential for a politically expedient deterinination is great. Moreover, uncertamty about the legality of succession might make people reluctant to follow the acting Governor's orders. ${ }^{94}$ Problems in determining whether action by a successor official is "necessary" may thus render an effective absence test inadequate. Second, the traditional effective absence rule, at least as interpreted by the Brown court, would still not permit a Governor to act while outside the state. This prohibition on out-of-state action makes little sense in an era when Governors are frequently called upon to leave the state on important business.

A second general approach is to preserve the strict absence rule, or some other definite and ascertainable determinant for succession, but to structure governmental organization so as to diminish the likelihood that a Lieutenant Governor will act contrary to the wishes of the Governor. Reform of this kind, such as requiring a single ticket for Governor and Lieutenant Governor, has often been suggested in recent

bility and continuity of the executive power." 26 Cal. $3 \mathrm{~d}$ at 117,603 P.2d at 1362, 160 Cal, Rptr. at 764.

92. Sawyer v. First Judicial Dist. Court, 82 Nev. 53, 57, 410 P.2d 748, 750 (1966).

93. The ascertainability of the moment of transition is a strength of the strict absence approach, but, as the rule is now applied, there may still be potential for confusion. If a Lieutenant Governor's power to act terminates the moment the Governor crosses, e.g., in an airplane, over the state line, the precise timing of that crossing becomes crucial. Illustration of the ludicrousness which this emphasis on border crossing may create was provided by Lieutenant Governor Curb's signing of the order relaxing air quality standards. See note 12, supra. Informed that a typographical error in the order had rendered it meaningless, Curb raced from San Francisco to Sacramento in order to be able to correct the error before Brown's airplane reentered California airspace. See also In re An Act Concerning Alcoholic Beverages, 130 N.J.L. 123, 31 A.2d 837 (1943).

94. See note 88 supra. 
years. ${ }^{95}$ The legislature has, in fact, adopted one of these suggestions, ${ }^{96}$ minimizing the Lieutenant Governor's ability to make judicial appointments.

A problem with this second approach is that it may be impossible to achieve reform that is certain to prevent recurrence of the situation presented in Brown. There are too many ways in which a Lieutenant Governor.genumely bent on usurpation can disrupt a Governor's administration. ${ }^{97}$ The legislature cannot provide for every contingency. For example, there is no guarantee that a Lieutenant Governor who is from the same pohitical party as the Governor might not pursue his own policies to the detriment of the Governor's.

Reform, if it is to be effective, must go to the source of the problem. It must reflect the fact that a hiteral absence approach artificially creates a legal disability where, because of advancements in transportation and communications technology, no inability to govern exists. The legislature should therefore eliminate literal absence as an automatic trigger for succession. In its place should be substituted a "continual authority" rule that would permit a Governor, subject to a narrow exception, to exercise the powers and duties of his office irrespective of his physical location.

The merits of such a rule are obvious. There would be no confusion over who held gubernatorial power at any given moment, since transfers of authority would be quite rare. The Governor would, furthermore, be able to act with full legal authority when representing the state on official business in Washington or elsewhere, and there would be no danger that an acting Governor might nullify actions taken by

95. Assemblyman William Lockyer has proposed that the Governor and the Lieutenant Governor be required to run on, and be elected from, a single ticket. Proposed Assembly Constitutional Amendment 10, Cal. Legislature, Regular Sess. (1979-80) (introduced December 5, 1978). More recently, Assemblyman Gary Hart proposed that the office of Lieutenant Governor be elimimated entirely, the legislature to designate a public officer to act as Governor during the impeachment, absence from the state, or other temporary disability of the Governor. Proposed Assembly Constitutional Amendment 13, Cal. Legislature, Regular Sess. (1979-80) (introduced December 14, 1978).

96. Government Code $\$ 12011.5$ requires the Governor to submit to the State Bar Board of Governors for its evaluation the names of all potential appointees to judicial positions to be filled by guberuatorial appomtment requiring confirunation, CAL. Gov'T CODE § 12011.5 (West 1979). Although the stated intention of the legislature im passing this bill was "to assist the Governor in the evaluation of nominees to judicial office" by increasing the quantity of information available to him, the bill's timing and the fact that its sponsor, Speaker McCarthy, had publicly criticized Lieutenant Governor Curb's appointment of Judge Arabian, suggest that the legislature inteuded also to mitigate the ability of a Lieutenant Governor to make judicial appointments by providing a 90-day period (the time alloted for the Board of Governor's evaluation) during which a Governor could return to the state and withdraw names submitted to the Board of Governors to which he was opposed.

97. See note 89 supra. 
the absent governor. ${ }^{98}$ In addition, a Lieutenant Governor could not, during a Governor's absence from the state, thwart the latter's policies because the Governor would remain in command. Fimally, the necessity to hurry action prior to departure, im order to prevent a Lieutenant Governor from acting, would likewise be eliminated, and any actions that needed to be taken would not have to await the Governor's return.

One important exception to the "continual authority" rule is required. Should the Governor, whether present im or absent from the state, ${ }^{99}$ be unavailable for consultation in an emergency situation requiring immediate executive action, the Lieutenant Governor would then assuine full gubernatorial power. The Lieutenant Governor would retain this power until the emergency ended or until the Governor could be contacted, whichever occurred first. An emergency situation, for purposes of succession, would be defined as one in which hife or property is imminently threatened. If the Governor could not be contacted and the Lieutenant Governor believed that an emergency existed, he would inform a designated state official, perhaps the Secretary of State or the Chief Justice of the suprene court. This official would have the authority to decide whether an einergency situation existed and whether it was impossible to reach the Governor witlim a reasonable time. If both conditions were found to exist, the Lieutenant Governor would be empowered to act with full gubernatorial authority until the emergency ended or until the Governor was contacted. In the event the designated official could not be contacted within a reasonable amount of time, the Lieutenant Governor could assume the Governor's powers, subject to the same termination provision, but would have to notify the designated official as soon as possible. The official, once contacted, would have the power to review and terminate the Lieutenant Governor's assumption of power.

One criticism of the continual authority approach is that it leaves a Lieutenant Governor with too much discretion. Under this approach, where the Lieutenant Governor is unable to contact the designated offcial, he inust himself determine if an emergency exists. Since this determination is soinewhat subjective, a Lieutenant Governor eager to

98. See 26 Cal. 3d at 129-30, 603 P.2d at 1370, 160 Cal. Rptr. at 772 (Newman, J., concur. ring) in which Justice Newman raiscd this very possibility as a justification for imposing an "effective absence" rule. Effective absence, however, could probably not adequately remedy the problem, because at least under the Brown court's imterpretation of that rule a Governor outside the state still would be legally disabled from acting with gubernatorial authority. (See text accompanying notes 53-54 supra.) Though his representations could not, under unost circuunstances, be undermined by the Lieutenant Governor, they would have no legal force.

99. The Governor could, for example, be unreachable if off on a backpacking trip in a remote corncr of the state. Note that the current California succession provision does not allow the Lieutenant Governor to exercise gubernatorial power when the Governor is in the statc-even if there is an emergency and the Governor cannot be contacted for some reason. 
wield gubernatorial power might conceivably abuse his discretion and declare an emergency where none in fact exists. The potential for abuse, however, is minimal. The designated official may terminate the Lieutenant Governor's ability to act as soon as the official learns of it. And the Lieutenant Governor's gubernatorial powers terminate once the Governor is reached. Moreover, occasions when an emergency situation coincides with both the Governor's and the designated official's inability to be located are, as a practical matter, likely to be very infrequent, thus affording even a Lieutenant Governor bent on usurpation little opportunity for abuse.

\section{CONCLUSION}

In holding that article V, section 10 of the Califorma Constitution automatically grants the Lieutenant Governor complete gubernatorial authority during a Governor's physical absence from the state, the supreme court in Brown v. Curb construed the provision in a manner consistent with its legislative history and contemporaneous construction. The court's decision, however, left open the possibility of further conflict between Governors and Lieutenant Governors. For this reason, and because today's communication systems enable a Governor to govern effectively even when traveling outside state borders, the legislature should change the literal absence rule. In particular, it should amend the constitution so that a Lieutenant Governor inay not automatically exercise gubernatorial power upon the Governor's departure from the state. The Governor should instead be empowered to act irrespective of his physical location, so long as state officials are able to contact him. If, in an einergency situation-one imminently threatening life or property-the state officials cannot contact the Governor, then the Lieutenant Governor, upon the approval of a designated official, should assunie full gubernatorial powers until the Governor is again able to be reached or until the emergency ends.

Richard H. Abramson*

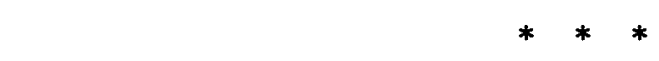

* B.A. 1978, Claremont Men's College; third-year student, Boalt Hall School of Law. 
Fair Political Practices Commission v. Superior Court. ${ }^{1}$ The court upheld the validity of the Political Reform Act of $1974^{2}$ against the claim that it violated the single subject rule for intitiative ineasures. The court, however, struck down several sections that regulate lobbyists.

The inajority held that the Act did not violate the California Constitution's prohibition of "initiative measures embracing inore than one subject," 3 even thougl the Act regulates campaign financing, lobbyist activities, conflicts of interest, voter painphlet summaries, and the ballot position of candidates. In upholding the initiative, the plurality opinion applied the test used for legislative ineasures-that all provisions of an enactment must be "reasonably germane" to its subjectand found that the Act passed muster. ${ }^{4}$ In concurrence and dissent respectively, both Justices Tobriner and Manuel argued that the proper test for an initiative is whether its provisions are "functionally related in furtherance of a common underlying purpose."5 Justice Tobriner found that the Act met this test; Justice Manuel found that it did not.

But after upholding the general validity of the Act, the court relied on Buckley v. Valeo ${ }^{6}$ to strike down as overbroad the Act's prohibition of political contributions by lobbyists. ${ }^{7}$ As examples of this overbreadth, the court noted that the Act prevented lobbyists froin contrib-

1. 25 Cal. 3d 33, 599 P.2d 46, 157 Cal. Rptr. 855 (1979) (Clark, J.) (plurality opinion), cert. denied, 48 U.S.L.W. 3465 (U.S. Jan. 1, 1980).

2. CAL. Gov'T CODE $\S \S 81000-91014$ (West 1976 \& Supp. 1980).

Other sections of the Act had already been struck down by the courts. Hardie v. Eu, 18 Cal. 3d 371, 556 P.2d 301, 134 Cal. Rptr. 201 (1976) (limitation on expenditures for circulation of initiative petitions); Citizens for Jobs \& Energy v. Fair Political Practices Comm'n, 16 Cal. 3d 671, 547 P.2d 1386, 129 Cal. Rptr. 106 (1976) (limitation on expenditures on statewide ballot propositions); Institute of Governmental Advocates v. Younger, 70 Cal. App. 3d 878, 139 Cal. Rptr. 233 (2d Dist. 1977) (prohibition on lobbyists advising their employers to make political contributions).

3. CAL. ConsT. art. II, \& 8(d).

4. $25 \mathrm{Cal} .3 \mathrm{~d}$ at 43,599 P.2d at $51,157 \mathrm{Cal}$. Rptr. at 860 . The lobbyists had argued that initiatives require a stricter test than legislative acts because voters may vote for all of an mitiative even though they support only one provision and because of the greater possibility of voter confusion. Justice Manuel, arguing the same position, noted that the consequences of violating the single subject rules are different: a statute einbracing a subject not in its title is void only as to that subject, while an initiative embracing unore than one subject is completely without effect. $25 \mathrm{Cal}$. 3d at 55 n.2, 599 P.2d at 63 n.2, 157 Cal. Rptr. at 872 n.2 (Manuel, J., dissenting).

5. Id. at 50, 599 P.2d at 55, 157 Cal. Rptr. at 864 (Tobriner, J., concurring), quoting Schmitz v. Younger, 21 Cal. 3d 90, 99-100, 577 P.2d 652, 657-58, 145 Cal. Rptr. 517, 522-23 (1978) (Manuel, J., dissenting); 25 Cal. 3d at 55, 599 P.2d at 63, 157 Cal. Rptr. at 872 (Manuel, J., dissenting).

In Anador Valley Joint Union High School Dist. v. State Bd. of Equalization, 22 Cal. 3d 208, 583 P.2d 1281, 149 Cal. Rptr. 239 (1978), the court applied both tests in upholding the JarvisGann initiative.

6. 424 U.S. 1, 22 (1976) (per curiam) ("“C]ontribution and expenditure limitations . . . impinge on protected associational freedoms. Making a contribution, like joining a political party, serves to affiliate a person with a candidate.").

7. CAL. Gov'T CODE $\S 86202$ (West 1976). 
uting to the campaigns of candidates whom they might never lobby, that it covered lobbyists who appear only before administrative agencies, and that it forbade even the smallest lobbyist contributions. The court held that these restrictions on lobbyists' first amendment right to freedom of association were too broad to be justified by the government's interest in eliminating actual and apparent corruption and improper influence.

The court also invalidated sections of the Act requiring lobbyists and their employers to report financial transactions with state candidates, state officials, members of their immediate families, and all businesses that such candidates or officials either owned or served as directors. ${ }^{8}$ Without passing on the coinpelling nature of the asserted state interests, it held that the interference with lobbyists' first amendment rights was not drawn narrowly enough to "avoid arbitrary and unnecessary curtailment of the protected freedom." Rather, it found, the sections unconstitutionally conditioned the lobbyists' right to petition for redress of grievances on "disclosure of irrelevant private financial matters" unrelated to lobbying activities. ${ }^{10}$ For example, said the court, if a Regent of the University of California was also a director of the Bank of America, all lobbyists would have to report transactions with the Bank, even though their lobbying had nothing to do with banks or the University.

The court upheld the Act's other lobbyist reporting provisions, as well as sections requiring lobbyists to register and sections restricting lobbyists' gifts to state officials and candidates. ${ }^{11}$ These provisions were held not to interfere substantially with first amendment rights.

Justice Newman and Chief Justice Bird, in separate opinions, dissented from the invalidation of the contribution prohibition and the transaction disclosure requirements. Justice Newman felt that the court had too narrowly defined the objectives of the Act. Chief Justice Bird argued that in order to protect the public's right to petition for redress of grievances the Act prohibited lobbyists from buying the ear of government officials. She further contended that since lobbyists are paid to influence government decisions, campaign contributions from lobbyists are different from ordinary campaign contributions and can therefore be totally prohibited. ${ }^{12}$ Justice Bird concluded that the

8. CAL. Gov'T CODE $\$ 86107$ (d) \& (e) and \$ 86109(d) \& (e) (West 1976).

9. $25 \mathrm{Cal}$. 3d at 49,599 P.2d at 55, 157 Cal. Rptr. at 864 .

10. Id.

11. The court upheld CAL. Gov't CODE $\$ \$ 86100-86107,86109,86201,86203$ (West 1976) with the exception of the subdivisions of $\$ \S 86107$ and 86109 cited in note 8 supra.

12. Chief Justice Bird noted that CSC v. Letter Carriers, 413 U.S. 548 (1973), had upheld a total ban on partisan political activity by government employees. 
court's holdings "gutted" an Act that served rather than damaged first ainendment values.

The court's holding in this case has two unfortunate consequences. First, by striking down the only existing restriction on lobbyist contributions, the court has removed all state regulation of campaign contributions by lobbyists and their employers. After this case, lobbyists are free both to inake political contributions theinselves and to advise their employers to make such contributions. Thus, not only can lobbyists purchase influence for their present employers, but they may also acquire a personal following among state officials by making campaign contributions in their own names.

Second, by mvalidatimg the transaction reportimg provisions, the court severely limited the situations in which lobbyist transactions with state officials must be disclosed. For example, under the provisions struck down by the court, a lobbyist or his employer who had all of his printing done by a business owned by a state legislator would have had to disclose the price for which this work was done. Now, lobbyists and their employers need only report "expenses which benefit in whole or in part any . . . state official . . . or member of [his] immediate family." 13 This requirement leaves it to the lobbyist or his employer to decide which transactions "benefit" the state official and therefore must be disclosed. It is extremely doubtful that this sort of discretionary disclosure will aid in the detection of illegal activities.

Agins v. City of Tiburon. ${ }^{1}$ The California Supreme Court determined that a landowner allegedly deprived by a zoning ordinance of substantially all use of his land may not seek damages for his loss under a theory of inverse condemnation. Rather, the remedies available to the property owner are limited to declaratory relief or mandamus. The court also addressed the question of the standard for constitutionality of a zoning ordinance, holding that an ordmance may be invalidated only when its effect is to deprive the owner of "substantially all reasonable use" of his property. ${ }^{2}$

13. Cal. Gov't Code $\$ 86105$ (b) (West Supp. 1980). See also Cal. Gov't Code $\$ \$ 82045(\mathrm{c})$ and $86109(\mathrm{c})$ which together require employers of lobbyists to report any payment to the lobbyist which directly or indirectly benefits any state official or nember of his faunily.

1. 24 Cal. 3d 266, 598 P.2d 25, 157 Cal. Rptr. 372 (1979) (Richardson, J.) (6-1 decision), cert. granted, 48 U.S.L.W. 3426 (Jan. 8, 1980).

2. Id. at 277,598 P.2d at 31,157 Cal. Rptr. at 378 . 
The Agins plaintiffs owned five acres of unimproved ridgeland in the City of Tiburon, which they had acquired for the purpose of residential developinent. Several years after their acquisition of the property, the city council adopted an ordinance ${ }^{3}$ designating the plaintiffs' land for single family residential or open space use. Because the maximum residential density in the classification was one house per acre, the classification as applied to plaintiffs' land limited its developinent to a maximum of five individual dwelling units. The plaintiffs filed a coinplaint against the city seeking two million dollars in damages under a theory of inverse condemnation, and, as a second cause of action, requesting that the court declare the zoning ordinance invalid as an unconstitutional attempt to take plaintiffs' property without paynent of just compensation.

The majority opinion characterized the case as presenting a question the court had declined to answer in the 1975 decision of HFH, Ltd. v. Superior Court. ${ }^{4}$ In $H F H$, the court held that a cause of action for damages in inverse condemnation could not be based on "mere diminution in the value of property" brought about by a restrictive zoning ordinance. ${ }^{5}$ The court, llowever, expressly declined to extend the ban on inverse condemnation actions to cases alleging deprivation of substantially all remaining use due to a restrictive zoning ordinance. ${ }^{6}$ Four years later, the Agins court, when faced with this allegation in an inverse condemnation action, rejected the cause of action on conceptual grounds and for reasons of public policy.

The court first dealt with the plaintiffs' argument that a city's exercise of its police power which exceeds constitutional limits is equivalent to a taking of property by eminent domain which requires the payment of compensation. Acknowledging that an unreasonable exercise of the police power could have the same effect as an action in eminent domain, the court cited authority that it could not be treated conceptually as a valid eminent domain action because no provision had been made for compensation. ${ }^{7}$ Instead, the proper remedy for an excessive use of the police power is invalidation through an action for declaratory relief or mandamus. The court buttressed this conceptual distimction by citing a number of policy considerations favoring invalidation over damages in inverse condemnation. The majority noted the "legitinuate needs" of government to plan freely and innovatively, to be able to

3. City of Tiburon, Cal., Ordinance No. 124 N.S., effective June $28,1973$.

4. 15 Cal. 3d 508, 542 P.2d 237, 125 Cal. Rptr. 365 (1975), cited in Agins v. City of Tiburon, $24 \mathrm{Cal} .3 \mathrm{~d}$ at 274, 598 P.2d at 31, $157 \mathrm{Cal}$. Rptr. at 378.

5. $15 \mathrm{Cal} .3 \mathrm{~d}$ at $518 \mathrm{n} .15,542 \mathrm{P} .2 \mathrm{~d}$ at $244 \mathrm{n} .15,125 \mathrm{Cal}$. Rptr. at $372 \mathrm{n} .15$.

6. Id. at 518 n. 16,542 P. $2 \mathrm{~d}$ at 244 n.16, 125 Cal. Rptr. at 372 n. 15 .

7. Id, citing 1 Nichols, LAW OF EMINENT Domain § 1.42(1), 1-116 to 1-121 (3d rev. ed. 1978). 
adjust to rapidly changing circumstances, and to prevent the fiscal chaos which the court feared could result from unanticipated commitments of public funds through the planning process.

The court next considered the standard of deprivation that must be demonstrated to obtain invalidation through declaratory relief or inandainus. Recognizing that the question of whether a regulation is excessive is one of degree, to be determined by the particular facts of each situation, the court specified the appropriate benchmark as "deprivation of substantially all reasonable use" of the owner's property. The majority found that the ordinance in question allowed the construction of soine residences, and tlierefore it did not unconstitutionally interfere with the plaintiffs' use of their land.

Justice Clark, in dissent, einphasized the harshness of zoning ordinance as a factual inatter to be accepted by the court in the context of a demurrer. Accepting on deinurrer the allegation that the ordinance completely destroyed the value of the plaintiffs' property for all purposes, the dissent found that the ordinance resulted in a taking under California case law. The dissent also viewed the inajority's refusal to allow a remedy in inverse condemnation as contrary to both state and federal law.

The Agins inajority viewed its analysis as a "balancing of the constitutional rights of the landowner against the legitimate needs of gov-

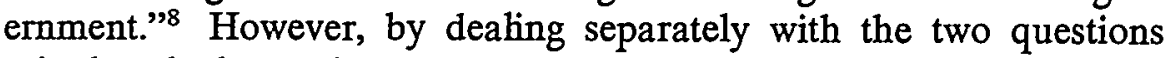
raised-whether an inverse condenunation claim may be asserted when a zoning ordinance is said to effect a taking, and the standard of constitutionality with respect to sucl an ordinance-the court may have been led to miscalculate the degree of threat posed by inverse condenination awards. Had the court applied the constitutional standard, "deprivation of substantially all reasonable use," to decide when an award of damages would be appropriate, it would have set a high threshold for inverse condemnation claims. Indeed, this standard inay be viewed as requiring a more severe deprivation than the "mere diminution in value" which the $H F H$ case held insufficient to state a taking. Numerous cases atteinpted to state a cause of action for "no reasonable use" following $H F H$, but no California appellate court has upheld a taking claim purely on this ground. ${ }^{9}$ Furthernore, $H F H$ has been read as

8. 24 Cal. 3d at 274,598 P.2d at 29, 157 Cal. Rptr. at 376.

9. See, e.g., Furey v. City of Sacramento, 85 Cal. App. 3d 464, 149 Cal. Rptr. 541 (3d Dist. 1978) (area zoned "permanent agricultural use" under open space ordinance did not give rise to claim of "no substantial reasonable use"); Friedman v. City of Fairfax, 81 Cal. App. 3d 667, 144 Cal. Rptr. 687 (1st Dist. 1978) (zoning for "commercial/recreational" use left "reasonable use"); Pan Pacific Properties, Inc. v. County of Santa Cruz, 81 Cal. App. 3d 244, 146 Cal. Rptr. 428 (3d Dist. 1978) (downzoning froin highway commercial to agricultural left a reasonable and beneficial use); Orsetti v. City of Freinont, 80 Cal. App. 3d 961, 146 Cal. Rptr. 75 (1st Dist. 1978) (downzon- 
portendimg a shift from an objective measure, remaining marketability, to a subjective measure, the use to which the property could be put by an imdividual who may or may not be economically motivated. ${ }^{10}$ If, im formally adopting the "no reasonable use" standard, the Agins court meant to endorse the subjective measure, the standard for taking will be very high, as most property can be imagimed to be useful in some way to someone. But even under less strict interpretations, the "deprivation of all reasonable use" standard substantially mitigates the threat to mnovative planning posed by damages in inverse condemnation. ${ }^{11}$

This failure to perceive accurately the degree of harm posed by inverse condemnation challenges to restrictive zoming was exacerbated by a failure to recognize the full degree of harm suffered by victims of unconstitutionally restrictive zoning and the absence of incentives to

ing from residential to agricultural left remaining value of $\$ 187,000$ ); Sierra Terreno v. Tahoe Regional Plannimg Agency, 79 Cal. App. 3d 439, 144 Cal. Rptr. 776 (3d Dist. 1978) (downzoning from commercial/mdustrial to general forest left reasonable use); Pinheiro v. County of Marin, 60 Cal. App. 3d 323, 131 Cal. Rptr. 633 (1st Dist. 1976) (downzoning with loss of value from $\$ 960,000$ to $\$ 210,000$; allegation that development is economically infeasible is not sufficient to qualify as "no reasonable use"); Dale v. City of Mountain View, 55 Cal. App. 3d 101, 127 Cal. Rptr. 520 (1st Dist. 1976) (golf course zoned for open space experienced a mere "diminution im value").

Only two cases succeeded in stating a cause of action in inverse condemnation for downzoning before Agins blocked the availability of the cause of action. In Eldridge v. City of Palo Alto, 57 Cal. App. 3d 613, 129 Cal. Rptr. 575 (1st Dist. 1976), an appellate court held that a cause of action was stated where a landowner did not challenge the validity of an ordinance but sought damages on an allegation that a restriction of minimun lot size to ten acres had effectively prevented any substantial or reasonable use of the property. Several cases have subsequently treated Eldridge, however, as also involving a taking for public use, since the ordinance in question made provisiou for public access to trails to be located on the plaimtiffs' property. See Pan Pacific Properties, Inc. v. City of Santa Cruz, 81 Cal. App. 3d 244, 146 Cal. Rptr. 428 (lst Dist. 1978); Frisco Land and Mining Co. v. State of Calif., 74 Cal. App. 3d 736, 759, 141 Cal. Rptr. 820 (1st Dist. 1977).

San Diego Gas and Electric Co. v. City of San Diego, 81 Cal. App. 3d Adv. Sh. 844, 146 Cal. Rptr. 103 (4th Dist. 1978) (opimion decertified), is the only California case in which damages were actually awarded in inverse condemnation as a result of downzoning. There, too, however, the outcoune was not determined solely on the grounds of deprivation of use. Although the property in question, a tidelands area, had a very limited number of uses due to its geographic situation, the court also considered the city's precondemnation activities to be imrportant factors. Id. at 864,146 Cal. Rptr. at 116-17. The case was transferred back to the Court of Appeals by the supreme court following the Agins decision; on reliearing, the court of appeal rejected the damage award. Calif. Court of Appeals No. 16277 (4th Dist. June 26, 1979).

10. See Note, Sizing Up Just Compensation Relieffor Down-Zoning after HFH and Eldridge, 10 U.C.D.J.. REv. 31, 45 (1977).

11. Apart from an interpretation of the standard as "any conceivable use," the "no reasonable use" standard may be read as: 1) retaining a standard of use based on marketability-the willingness of others to buy the land for the permitted use, see HFH, Ltd. v. Superior Court, 15 Cal. $3 \mathrm{~d}$ at 513 n.2, 542 P.2d at 240 n.2, 125 Cal. Rptr. at 368 n.2) (noting that economic value is "basically not an objective quahity, but a social attribute of legal rights"); 2) guaranteeing a profitable use of property, see Friedınan v. City of Fairfax, 81 Cal. App. 3d 667, 676 n.2, 146 Cal. Rptr. 687, 693 n.2 (Ist Dist. 1978) (reciting trial court finding of "no reasonably viable economic use"); 3) holding as reasonable per se any ordinance that allows the continuation of an existing use, see Furey v. City of Sacramento, 24 Cal. 3d at 872, 598 P.2d at 849, 157 Cal. Rptr. at 689; HFH, Ltd. v. Superior Court, 15 Cal. 3d at 516, 542 P.2d at 242, 125 Cal. Rptr. at 370. 
respect property rights in a system remedied solely by declaratory relief. Although future costs may be covered by invalidation of the offending ordimance, property owners can incur costs while an excessively harsh ordinance is in effect; these costs were lield to be nonrecoverable in a mandate action by the $H F H$ court. ${ }^{12}$ For example, mability to put property to a profitable use may result im foreclosure on a inortgage. Obviously, invalidation will little benefit the former owner who was forced off his property. ${ }^{13}$ A similar situation may arise wliere the property imterest taken is an option to purchase that expires before the imvalidation remedy is applied. ${ }^{14}$ Property taxes, ${ }^{15}$ lost rental imcome, and inaintenance expenses are additional "holding" costs of taking that will not be covered by declaratory relief or mandate. Sucl damages have been recognized in other types of taking cases ${ }^{16}$ and probably would not be a substantial boon to the restricted property owner nor a significant hardship on the local government found to have restricted property rights unconstitutionally. Yet they would assure that the property owner would be compensated to the full extent that his property was illegally restricted, and tliey would offer some disincentive to the land regulator agamst pushing restrictions to the point of sucli unconstitutionality. Unfortunately, the Agins decision made no attempt to assess the feasibility of such imterim damages, choosing only to consider the general question of inverse condemnation as an award of full market value for transferral of property title to the government.

While the Agins decision in no uncertain terms ruled out inverse condemnation claims in cases involving downzoning, two other types of inverse condemnation cases survive the Agins rationale. These categories, cases of inequitable precondemnation activities by the govern-

12. $15 \mathrm{Cal} .3 \mathrm{~d}$ at $520,542 \mathrm{P} .2 \mathrm{~d}$ at $245,125 \mathrm{Cal}$. Rptr. at 373 .

13. For an example of how this situation may arise, see Klopping v. Whittier, 8 Cal. 3d 39, 500 P.2d 1345, 104 Cal. Rptr. 1 (1972). Because that case involved inequitable precondemnation, damages were paid to a property owner/plaintiff who had been forced to sell his property in the interim.

14. See the post-Agins decision of Toso v. City of Santa Barbara, 101 Cal. App. 3d 934, 162 Cal. Rptr. 210 (2d Dist. 1980), allowing an inverse condemnation action to be brought based on the city's unreasonable precondemnation activities that oceurred during the period of time the plaintiff held an option to purchase the affectcd property, even though the plaintiff allowed the option to expire prior to resolution of his lawsuit.

15. For a discussion of the understatement of the effects of land use restrictions in state property tax assessments, see Comment, The Dilemma of Preserving Open Space-How to Make Californians an Offer They Can't Refuse, 13 SANTA ClaRA Law. 284, 287-89 (1972).

16. See City of Los Angeles v. Lowensohn, 54 Cal. App. 3d 625, 633-35, 127 Cal. Rptr. 417, 422-23 (2d Dist. 1976); Stone v. City of Los Angeles, 51 Cal. App. 3d 987, 124 Cal. Rptr. 822 (2d Dist. 1975). 
ment, ${ }^{17}$ and cases of zoning for public use, ${ }^{18}$ were preserved in $H F H,{ }^{19}$ and nothing in the Agins decision would appear to foreclose recovery of damages in such instances. At least one case with elements of a public use allegation lias been upleld by the supreine court since Agins. ${ }^{20}$ Inequitable precondenination cases seein even more secure as the Agins court cited the precondenination cases without criticizing thein. ${ }^{21}$

The federal courts inay offer a final resort for victimized property owners seeking dainages for restricted use after Agins. The federal courts have long recognized a cause of action for inverse condemnation, but to the extent that damages actually have been awarded, they have been given in cases of precondemnation bliglt or public use, for which damages arguably still are permitted after Agins. However, a new trend in federal case law appears to be increased municipal liability in damages for government violations of federal constitutional

17. See, e.g., Klopping v. City of Whittier, 8 Cal. 3d 39, 500 P.2d 1345, 104 Cal. Rptr. 1 (1972); Peacock v. County of Sacramento, 271 Cal. App. 2d 845, 77 Cal. Rptr. 391 (3d Dist. 1979). As the label implies, causes of action in inverse condemnation for inequitable precondemnation activities have been read as limited to fact situations where a public agency eventually intended to acquire the affected property through eminent domain. See HFH, Ltd. v. Superior Court, 15 Cal. 3d at $516 \mathrm{n} .14,542$ P.2d at 243 n.14, 125 Cal. Rptr. at $371 \mathrm{n} .14$.

18. Sneed v. County of Riverside, 218 Cal. App. 2d 205, 32 Cal. Rptr. 318 (4th Dist. 1963) (air navigation easeinent taken by height restriction allegedly limiting use to structures of less than three inches), is the most frequently cited public use case. Subsequent cases have indicated a tendency to read the requirement of public use literally. Courts have rejected causes of action for downzoning to agricultural use where actual, present use could be stated. See, e.g., Pinheiro v. County of Marin, 60 Cal. App. 3d 323, 328, 131 Cal. Rptr. 633, 636 (1st Dist. 1976); Morse v. County of San Luis Obispo, 247 Cal. App. 2d 600, 603, 55 Cal. Rptr. 710,712 (2d Dist. 1967). Cases involving zoning ordmances granting public access to private property have stated a cause of action in inverse condemnation. Bahl v. City of Palo Alto, 372 F. Supp. 647 (N.D. Cal. 1974); Eldridge v. City of Palo Alto, 57 Cal. App. 3d 613, 129 Cal. Rptr. 575 (1st Dist. 1976).

19. 15 Cal. 3d at 516-17 nn.13 \& 14, 518, 542 P.2d at $242-43$ nn. $13 \& 14,244,125$ Cal. Rptr. at $370-71 \mathrm{nn} .13 \& 14,372$.

20. Furey v. People of Sacramento, 24 Cal. 3d 862, 598 P.2d 844, 157 Cal. Rptr. 684 (1979), involved local government imitiation of sewer improvenents on undeveloped land that were financed by assessing the affected property owners. While not specifically described as such, the case may easily be read as one involving a taking for public use since the amount by which the assessed costs exceeded the benefits received was described as "a taking under the guise of taxation of private property for public use without compensation." Id. at 874, 598 P.2d at 851, 157 Cal. Rptr. at 691, quoting Norwood v. Baker, 172 U.S. 269, 279 (1898). The court also described the construction on plaintiffs' land as "public improvements" and emphasized that they were created by government imitiative. $24 \mathrm{Cal}$. 3d at $875,598 \mathrm{P} .2 \mathrm{~d}$ at $852,157 \mathrm{Cal}$. Rptr. at 692.

21. $24 \mathrm{Cal} .3 \mathrm{~d}$ at $278,598 \mathrm{P} .2 \mathrm{~d}$ at 31-32, $157 \mathrm{Cal}$. Rptr. at 378-79.

The contention that Agins has overruled these cases already lias been squarely rebutted by one appellate decision. See Toso v. City of Santa Barbara, 101 Cal. App. 3d 934, 162 Cal. Rptr. 210 (2d Dist. 1980). The court stated that

there is nothing in the Agins case to suggest that [an inequitable precondenination] cause of action is not still legally valid. Agins merely leeld that the particular conduct of the City of Tiburon did not amount to unreasonable condemnation activities. It did not hold that, under other circumstances, a city's precondemnation activities could not be such that there would be a cause of action for damages.

Id. at 952, 162 Cal. Rptr. at 220. 
rights under section $1983 .^{22}$ Since Agins purports to limit such liability, it may conflict with this federal trend.

22. 42 U.S.C. $\$ 1983$ (1975). See Monell v. Department of Social Servs., 436 U.S. 658 (1978) (holding that $\S 1983$ is applicable to municipal decisionmaking under certain conditions). The validity of $\S 1983$ as a jurisdictional ground for an award of damages and declaratory relief in cases of downzoning was recently upheld in Lake County Estates v. Tahoe Regional Planning Agency, 440 U.S. 393, 400 (1979). 